International Medical Society http://imedicalsociety.org

\title{
Use of Antioxidant Substances in Intestinal Anastomosis in Rats
}

Andrey de Almeida Carneiro', Paula Lavigne de Sousa Costa², Bernardo Felipe Santana de Macedo3, Maria Eduarda Silveira Bührnheim ${ }^{3}$, Edson Yuzur Yasojima4, Francisca Regina Oliveira Carneiro 5

\section{Abstract}

Introduction: Intestinal anastomosis consist of surgical procedures which there is an anastomotic line between two intestinal segments in order to reconstruct or divert the digestive transit. However, several complications may result from this surgical procedure.

Objective: Present, describe and discuss the findings of the literature regarding substances capable of reducing injury and possible complications of intestinal anastomosis.

Method: The data were collected by literature review using the descriptors: "intestinal anastomosis", "antioxidants"; and as basis articles published in the published Scientific Electronic Library (Scielo), Lilacs, MedLine and Pubmed databases. Inclusion criteria were original and review articles published in full in the online form in the Portuguese, Spanish and English languages, using the descriptors mentioned above in the respective languages.

Results: Scientific articles were collected, in which 38 papers were included in the inclusion criteria.

Conclusions: The major parts of substances described in the present study demonstrated be statistically relevant results and the capacity to optimize the anastomotic healing.
1 Graduate Medical Studant, University Center of Pará State (CESUPA), Brasil

2 GraduateMedical Stuadant,Metropolitan CollageofAmazon(UNIFAMAZ), Brasil.

3 GraduateMedical Stuadant,StateUniversityof Pará(UEPA), Brasil.

4 PhD, Full Professor, Medical School,StateUniversityof Pará CESUPA, Brazil.

5 PhD, Full Professor, Medical School, StateUniversityof Pará (UEPA), Brazil.

\section{Contact information:}

\section{Andrey de Almeida Carneiro.}

Address: Viscondi De Souza Franco, 625. Apto 3401.

”andreyalmeidac@gmail.com 


\section{Introduction}

Intestinal anastomosis consist in basic surgical procedures based in the confection of a suture, called anastomotic suture line, between two intestinal segments, in order to reestablish or divert digestive transit. The procedure is relatively simple; however, it may evolve with a number of complications, which some can be avoided by the use of antioxidant substances. [1]

Complications can vary from stenosis, dehiscence, suture loosening, and occurs in 5 to $10 \%$ of gastrointestinal anastomosis cases, leading to content overflow. [2] Fistulas are also anoccurrence that extend post-op time, and are responsible for 20 to $80 \%$ of post-op deaths through its complications, such as abscesses, sepsis and peritonitis. [3]

The success in the confection of anastomosis is directly connected to the use of correct techniques by the surgeon and the healing process, that involves the activation of macrophages, fibroblasts, vascular neoformation and collagen synthesis. For that, it is necessary that reactive oxygen species (ROS) not to be produced in excess, as the presence of considerable amounts of ROS leads to a range of negative effects in the organism, especially through modifications in cell signaling, membrane lipid peroxidation, exocyclic adducts, which can be associated to atherosclerosis chronic processes, neurodegenerative diseases, diabetes, carcinogenesis, mutagenesis, among others. [4]

Those substances are naturally produced in energy synthesis during metabolic enzymatic reactions in the mitochondria to producemetabolic water, that due to having unpaired electrons in the last valence shell, escape mitochondrial metabolism. Those components are counterbalanced by the synthesis of natural antioxidant agents in the organism, and are a bioactive compound capable of structurally and functionally maintaining cells trough the efficient degradation of oxidant compounds, lipid inhibition and peroxidation reactions. This prevents oxidative damage and has anti-inflammatory and anti-carcinogenic effects $[4,5]$. The lack of balance between oxidant and anti-oxidant agents leads to oxidative stress [6]. Various substances have been indicated and studied to assist in intestinal anastomosis healing process, prevent its complications and oxidative stress. Examples are melatonin [7] and substances with high rates of polyphenols and vitamins that have known effects in citric fruits. In contrast, others may cause dehiscence, such as corticosteroids [1].

Thus, this article aims to gather and analyzecritically the main findings in medical literature related to antioxidant substances and its influence in gastrointestinal anastomosis.

\section{Method}

For construction, this article used the PRISMA method, which consists of a list with 27 topics that serve to organize and direct the construction and elaboration of systematic literature reviews. Information was obtained from research in data bases such as BIREME, DECS and PUBMED, by the use of the keywords "anastomosis", "antioxidant" and "rats", all in intersection relations, in three languages (Spanish, Portuguese and English). 38 articles that followed inclusion criteria were selected.

\section{Review}

\section{Intestinal Anastomosis}

Intestinal anastomosisconsist of the surgical communication between two organs. Those procedures are of reoccurring use in digestive treat surgeries, with the main goal being to reconstruct the digestive tract as a result of tumors, necrosis due to thrombosis and peptic ulcers, or a digestive transit digression in obstructive scenarios. Its confection may be done by large procedures or by the use of minimally invasive techniques, using sutures or a stapler. [8, 9]

Gastrointestinal anastomosis can be classified according to stumps, anastomotic mouth size, lo- 
cation, layers and planes. The stumps may be endto-end, latero-lateral and end-lateral. While the openings may be oralisparcialis and oralistotalis. Regarding the location they can be esophagojejunal, gastroenteric and entero-enteroanastomosis. In addition, the sutures may be partial or total, in 1 or more levels. [10, 11]

After the surgical procedure, it is necessary to use evaluation maneuvers in order to evaluate the existence of alterations and prevent postoperative complications. For that, the ring and the borrower maneuvers are used in humans. The first one consists of touching the light of the involved organs through the wall of the organ, in order to check the permeability of the anastomosis, ensuring that the digestive flow is adequate. The second consists of inflating in the anastomosed region, througha rectal or nasogastric tube and subsequent placement of water or saline solution around this region. If there is no formation of air bubbles near the area, it is considered that the anastomosis was made correctly [16].

Complications from this kind of surgical procedure may include stenosis, that consists of the pathological narrowing of the tube lumen, usually due to an elevated amount of fibrous tissue that slows down the digestive flow, as well as fistulization, necrosis, anastomotic line dehiscence, and usually as a consequence of suture dehiscence, leakage of the gastrointestinal content and may progress to septic peritonitis. In this procedure, dehiscence is the major complication faced, being directly linked to other complications such as gastrointestinal leakage and septic peritonitis. Such complications compromise clinical outcomes and require repair surgery, resulting in a significant increase in treatment cost, morbidity and mortality $[12,13,14]$.

For this reason, familiarity with local anatomy, technical care and techniques should be in the surgeon's domain, in order to avoid possible complications and allow a satisfactory recovery process.

\section{Intestinal anastomosis in experimental surgery}

Anasmotosis are widely used in experimental surgeries, with the main goal to find new less invasive techniques or test new substances that speed the healing process and reduce surgical damage $[15,16]$.

Therefore, knowledge of the techniques is required to the its appropriate usage and achievement of valid results that can be used to the development of new methods that assist human treatments. For that to be possible, the researcher needs to have extended knowledge about the anatomy and anatomical variations of the animalin which the procedure will be applied [17].

In experimental surgery, anastomosis security is assessed by the evaluation of rupture pressure and the rupture resistance test. According to Durães et al. [18], the pressure test is the most appropriate to evaluate anastomotic integrity and the risk of leakage, that usually happen in weakened areas in the anastomosis, besides being the best to evaluate inflammatory healing. However, the rupture resistance test offers a better overall analysis of the anastomosis.

Anastomosis performance varies according to several factors such as the chosen species, the region undergoing surgery, the techniques used by the surgeon, the suture type for the anastomotic line, anesthetics and analgesics in addition to the materials used. Therefore, the use of anastomosis can occur in different ways according to the researcher's objective, Thus, Brito et al. [19] described anastomosis of the small intestine as a procedure initiated from continuous inhalation of ether for anesthesia, and the later performance of the anastomosis between the duodenum and the ileocecal valve after $0.5 \mathrm{~cm}$ segmental resection. An extra-mucous single-plane end-to-end anastomosis was employed, using 6-0 polypropylene monofilament suture with an atraumatic needle.

Conversely, Chaturvedi et al. [20] demonstrated a surgical procedure by administering analgesics, such 
as buprenorphine in $0.02 \mathrm{mg} / \mathrm{kg}$ concentration, subcutaneously 30 minutes before surgery. After that, rats were anesthetized by inhalation of a isoflurane (3\%) and 1: 1 surgical oxygen pressurized air mix. All rats underwent a midline laparotomy and a 0.5 $\mathrm{cm}$ segment of the ileum was extracted, $15 \mathrm{~cm}$ proximal to the cecum. Ileal continuity was restored by an inverted single layer end-to-end anastomosis with eight sutures done with 8-0 monofilament material. Azevedo Coutinho et al. [21] also performed small intestine anastomosis in male dogs, that underwent anesthesia with sodium pentobarbital in a $30 \mathrm{mg} / \mathrm{kg}$ concentration. First, the procedure started with a jejunum cross section, $30 \mathrm{~cm}$ from the duodenojejunal flexure, followed by an end-toend anastomosis using the total single-level suture technique, the anterior half of the anastomosis was sutured on the serous surface and the posterior half was tied over the mucous layer in the lumen of the organ. Separate single stitches of 4-0 blue monofilament polypropylene, pre-assembled with $2 \mathrm{~cm}$ needle (3/8 circle), $3 \mathrm{~mm}$ apart, were used.

With that in mind, the researcher must verify the viability of the Project, worrying about the species that will be used and the animal's well-being,through the appropriate use of anesthetics and materials during the procedure. Thus, researchers need solid scientific proof for the research, and needs to be conscious of the moral responsibility of their acts.

\section{Use of antioxidant substances in intestinal anastomosis}

\section{Ascorbic acid}

Ascorbic acid is essential in collagen hydroxylation procedure and is required for tissue repair process, in addition to that, it helps capturing oxygen and preventing ROS formation, therefore acting as an antioxidant. [11] Based on previous study protocols, Petroianu et al. [22] acquired promising results when performing hydrocortisone and vitamin $C$ administration in rats, starting 3 days before intestinal anas- tomosis. It was shown that the group that received vitamin $C$ had more suture tension when compared to the control group. In addition, there was no decrease in suture resistance with hydrocortisone administration neither in short or long term. Thus, it is discussed that vitamin $C$ may be beneficial in preventing complications. However, further studies on the effects of corticosteroids on gastrointestinal anastomosis are needed. In another study, Petroianu et al. [23] administered only vitamin C 3 days before the surgical procedure and throughout the postoperative period of the animal. Evaluations were made on the 3rd, 5th, 7th, 21st and 28th day. The results showed an increase in healing tension both in immediate and late postoperative period in the group that took vitamin C. Nevertheless, it also highlights that the use of vitamin $C$ increases the chances of late rupture of the intact jejunal segment, and further studies are needed to elucidate its mechanism of action.

\section{Argan Oil}

Argan Oil, is obtained from Argania spinose L, from South Morroco. It is usually used as topical medication in various diseases, such as acne, eczema and psoriasis; besides being used in cosmetics, as shampoos. It is rich in oleic and linoleic fatty acids, and vitamin $E$, being mostly known for its antioxidant, anti-inflammatory, anti-hypercholesterolemia, anti-carcinogenic, anti-acne, anti-obesity, anti-aging and anti-glycemic properties. [24, 25]

Aiming to investigate its antioxidant power, Barlas et al. [26] performed colon anastomosis in 30 female rats, applying argan oil in the suture line of the experimental group and $\mathrm{NaCl} 0,9 \%$ the control group. After that, during the post-op, both substances were rectally applied in its respective groups for 8 days, until the animals were euthanized. It was seen that argan oil presented a better scenario concerning rupture pressure, histopathologic findings, prolidase activity and hydroxyproline levels. 


\section{Melatonin}

Melatonin is a hormone produced in the pineal gland and has antioxidant properties, acting through the increase of antioxidant enzyme levels. In addition to that, it is responsible for the activation of mitogen activated protein kinases (MAPK) and nuclear-kappa factor (NF-K), which act on DNA modulation and damage repair. Its effects had already been described in other organs, such as the heart, kidneys, intestines, lungs and liver. [9]

In order to relate such effects to anastomosis protection, Ozhan etal. [27] performed an occlusion of the superior mesenteric artery and an ileoileal end-to-end anastomosis. The results showed that melatonin can prevent the harmful effects of ischemia and reperfusion processes on intestinal anastomosis.

\section{Carnitine}

L-Carnitine is an amino acid endogenously produced from lysine and methionine. It has known effects on ROS inhibition, in situations as preventing muscle loss in sepsis,. In this sense, Ercan et al. [28] performed colonic anastomosis and daily administered carnitine intraperitoneally in sepsis models in rats until the 5th post-op day. The results found that carnitine has protective effects on anastomosis, even in conditions that affect the healing process, such as sepsis.

\section{Hypothermia}

Hypothermiais a mechanismknowntoreducemetabolic processes byinterferingin theoxidative stressprocess. Oliveira et al. [29] performed hypothermia $\left(35^{\circ}\right)$ onthe 7th and 14th postoperative days of colonanastomosis. This experiment determined that hypothermia reduced the amount of superoxide dismutase and catalase enzymes, reducedglutathione, and increase lipid peroxidation in the anastomoti chealing process.

\section{GH and Ghrelin}

Ghrelin is an orexigenic hormone associated with GH secretion by stimulating its receptors and appetite regulation. In addition to these functions, ghrelin has immunomodulator, anti-inflammatory and anti-oxidant effects. Wheeless et al. [30] pointed out the positive effects of $\mathrm{GH}$ on terminal ileal anastomosis in radiation-treated rats, while Karahasanoglu et al. [31] also suggested that GH strengthens left colon anastomosis in rats. Based on the pathophysiological basis that ghrelin stimulates $\mathrm{GH}$ in humans, Ceran et al. [32] applied ghrelin, which did not affect fibroblast infiltration or neovascularization at the anastomotic site of the colon, but tests for resistance to rupture showed improvement.

\section{Caffeicacidphenethylester (CAPE)}

CAPE is a flavonoid like and is the active ingredient of propolis obtained from the bark of coniferous trees. It is known to have anti-inflammatory, antioxidant and anti-cancer properties, as it works by changing the arachidonic acid cascade and inhibiting leukotrienes and prostaglandins. Considering that anastomosis performed in cases of peritoneal sepsis has a high risk of dehiscence, Teke et al. [33] aimed to evaluate the effects of CAPE on the healing left colon anastomosis in rats with septic peritonitis. Among the results, it was pointed out that this acid significantly improved the process even in the presence of septic peritonitis, which was clearly an obstacle to healing, which was evidenced by the reduction in anastomotic rupture pressure and increased inflammation levels in histopathology. However, all these characteristics were prevented in the group that received CAPE. In another study, the same author also sought to investigate the effects of CAPE on the healing of left colon anastomosis followed by superior mesenteric artery (SMA) ischemia and reperfusion (RI). It was concluded that the $\mathrm{RI}$ process in the SMA impaired the healing process and increased inflammation around the anastomosis, which was reduced by the use of CAPE. 


\section{Eritropoetina}

Preoperative radiotherapy is used in the standard rectal cancer treatment, however it has been shown to have no positive effects on the healing of colonic anastomosis, as it directly or indirectly stimulates the release of ROS and damages DNA. In this sense, Turku et al. [34] sought to investigate the effects of an anti-oxidant substance in rats that underwent preoperative radiotherapy. This substance is Erythropoietin (EPO), a hormone produced in the kidneys and other tissues and has mainly hematopoietic effect. However, new studies have also pointed to anti-apoptotic and anti-oxidant effects. The results showed that some deleterious effects of radiotherapy were prevented by reducing oxidative stress, necrosis and inflammation.

\section{Bevacizumab}

Bevacizumab is an antibody anti-VEGF (anti vascular endothelial growth factor), immunoglobulin found in healing tissues and malignant diseases, responsible for local angiogenesis. Therefore, bevacizumab is commonly used in association with chemotherapy in the treatment of metastatic colon cancer, as it acts blocking tumor angiogenesis. In this regard, Pavlidis et al. [35] aimed to determine the effects of this antibody on colonic anastomosis in euthanized rats, both on the 7th and 14th postoperative days. However, there were no statistically relevant results regarding the use of this substance in the healing of colonic anastomosis.

\section{Protein Supplement (Whey)}

Whey is a dairy product composed of whey proteins with various biological effects, including antioxidant and immunity enhancing mechanisms. Those effects are mediated by increased glutathione (intracellular substance responsible for antioxidation) levels. [36] Aiming to correlate such effects with anastomosis healing process, Velioglu et al. [37] performed colonic anastomosis on rats and fed them with whey supplementation for 3 weeks. The supplementation group had significantly higher levels of glutathione and lipid peroxide. Reductions in lipid peroxidation were shown, evidencing its antioxidant effect. However, there were no differences in hydroxyproline content and rupture pressure between the whey group and the control group. Further studies are needed to define its specific role in anastomosis.

\section{Propolis}

Propolis is the generic name to the substance collected by bees, widely used by lay people. It has more than 180 substances in its formulation, which can vary according to the source. Propolis acts inhibiting lipoxygenase, cyclooxygenase, glutathione S-transferase, xanthine oxidase and others. Therefore, it is described as an anti-inflammatory and antitumor substance. Then, Temiz et al. [38] evaluated the effects of propolis on the healing of intestinal anastomosis in wistar rats, describing that this substance, regardless of its administration form, had significantly favorable healing results on intestinal anastomosis.

\section{Conclusion}

Healing process involving intestinal anastomosisis being described in various studies as a complex pathophysiological mechanism that is directly connected to oxidative stress. That results in complications that represent a huge concern in the surgical field. With that in mind, scientific researches highlight substances that can potentially reducethose complications, such as ascorbic acid, argan oil, propolis, melatonin, $\mathrm{GH}$, ghrelin, CAPE, erythropoietin, whey, bevacizumab and carnitine. Procedures, as hypothermia are also used. Most articles found had statistically relevant results that confirmed the use of those techniques as a way of improving anastomotic healing, showing the possibility of its therapeutic use in the pharmaceutical industry and the need to extent researches related to the properties and procedures here mentioned. 


\section{References}

1. Cha J., Shademan A., Le H. N. D., Decker R., Kim P. C. W., Kang J. U., Krieger A. (2015). Multispectral tissue characterization for intestinal anastomosis optimization. Journal of Biomedical Optics, 20(10), 106001. doi:10.1117/1.jbo.20.10.106001

2. Yuan, Y., Wang, K.-N., \& Chen, L.-Q. (2014). Esophageal anastomosis. Diseases of the Esophagus, 28(2), 127-137. doi:10.1111/dote.12171

3. De Nardi, P., Panzeri, F., \&Staudacher, C. (2008). Prospective trial evaluating new circular and linear stapler devices for gastrointestinal anastomosis: preliminary data. Techniques in Coloproctology, 12(1), 69-72. doi:10.1007/s10151-008-0401-2 .

4. Campos M.T.G., Leme F.O.P.(2018) Estresse oxidativo: fisiopatogenia e diganóstico laboratorial. Pubvet, v.12, n.1, a10, p.1-8, Jan.

5. Zou Z., Xi, W., Hu, Y., Nie, C., \& Zhou, Z. (2016). Antioxidant activity of Citrus fruits. Food Chemistry, 196, 885-896. doi:10.1016/j.foodchem.2015.09.072

6. Reiter, R. J., Mayo, J. C., Tan, D.-X., Sainz, R. M., AlatorreJimenez, M., \& Qin, L. (2016). Melatonin as an antioxidant: under promises but over delivers. Journal of Pineal Research, 61(3), 253-278. doi:10.1111/jpi.12360

7. Martins F. J., Caneschi C. A., Vieira J. L. F., Barbosa W., Raposo N. R. B. (2016). Antioxidant activity and potential photoprotective from amazon native flora extracts. Journal of Photochemistry and Photobiology B: Biology, 161, 34-39. doi:10.1016/j. jphotobiol.2016.05.012

8. Chadi S. A., Fingerhut A., Berho M., DeMeester S. R., Fleshman J. W., Hyman N. H., Wexner S. D. (2016). Emerging Trends in the Etiology, Prevention, and Treatment of Gastrointestinal Anastomotic Leakage. Journal of Gastrointestinal Surgery, 20(12), 2035-2051. doi:10.1007/s11605-016-3255-3

9. Rocha, J.R. (2011). Estomas intestinais (ileostomias Estomas intestinais (ileostomias e colostomias) e anastomosis e colostomias) e anastomosis intestinais intestinais. Medicina (Ribeirão Preto) 2011;44(1): 51-6

10. Kano M, Hanari N, Gunji H, Hayashi H, Matsubara H.( 2017). Is "functional end-to-end anastomosis" really functional? A review of the literature on stapled anastomosis using linear staplers. Surg today.

11. Junior C.S,; De Souza C., Gomes C.A., Soares F.P.T.P. (2010). Fatores intervenientes e métodos de avaliação das anastomosis gastrointestinais. Rev. Méd., Minas Gerais, v. 20, n. 3, 2010.

12. Blumetti J, Abcarian H. (2015). Management of low colorectal anastomotic leak: preserving the anastomosis. World J Gastrointestsurg. 2015.

13. Corsi P.R., Kanashiro E., Schiola A.; Cretella C.M., Gagliardi D.(2000).Tratamento cirúrgico das complicações da anastomose esôfago-visceral cervical. Rev. Col. Bras. Cir., v. 27, n. 5, p.293297, set./out. 2000.
14. Paixão R.L. (2001) Experimentação animal: razões e emoções para uma ética. Rio de Janeiro: Fundação Oswaldo Cruz, Escola Nacional de Saúde Pública;

15. Feng, Chung Wu, et al. (2003). Estudos biomecânicos da ação de aderências sobre anastomose cólica: trabalho experimental em ratos. Acta Cirúrgica Brasileira, 2003.

16. Hendriks, T., Mastboom, W. J. B. (1990). Healing of experimental intestinal anastomosis. Diseases of the Colon \& Rectum, 33(10), 891-901. doi:10.1007/bf02051930

17. Hendriks, T., Mastboom, W. J. B. (1990). Healing of experimental intestinal anastomosis. Diseases of the Colon \& Rectum, 33(10), 891-901. doi:10.1007/bf02051930

18. Durães L.C., Durães E.F.R., Lobato L.F.C., Ol-iveira P.G, Sousa J.B. (2013) Correlation between bursting pressure and breaking strength in colonic anastomosis. Acta Cir. Bras. [Internet]. Available from: http://www.scielo.br/scielo.php?script=sci art text\&pid=S010286502013000600008\&lng=en. http://dx.doi. org/10.1590/S0102-86502013000600008.

19. Brito M.V.H., Koh I. H. J., Lamarão L. G., Damous S. H. B. (2001) Efeito do choque hipovolêmico na anastomose do intestino delgado de ratos. Arq Gastroenterol V. 38, n. 2, abri/jun.

20. Chaturvedi, A. A., Yauw, S. T. K., Lomme, R. M. L. M., Hendriks, T., \& van Goor, H. (2017). Safety and Efficacy of Alginate Adhesion Barrier Gel in Compromised Intestinal Anastomosis. Surgicallnfections, 18(6), 670-675. doi:10.1089/sur.2016.086

21. Chaturvedi, A. A., Yauw, S. T. K., Lomme, R. M. L. M., Hendriks, T., \& van Goor, H. (2017). Safety and Efficacy of Alginate Adhesion Barrier Gel in Compromised Intestinal Anastomosis. SurgicalInfections, 18(6), 670-675. doi:10.1089/sur.2016.086

22. Azevedo J. L. M., Silva C. E. D., Azevedo O. C., Simões M. J., Kobayashi L. A., Kozonara M. (2004) Técnicas de sutura do tubo digestivo em plano único total em jejuno de cães: pontos de gambee com nós atados na serosa versus pontos totais atados no lumen, sobre a mucosa. Acta cirúrgica brasileira, vol. 19 (2).

23. Petroianu A., Alberti L. R., Souza S., Martins S. G. Efeito do ácido ascórbico e da hidrocortisona na cicatrização anastomótica intestinal. (2009) Rev. Col. Bras. Cir. [Internet]. 2009 Available from: http://www.scielo.br/scielo.php?script=sci_arttext\&pid=S 010069912009000600009\&lng=en. http://dx.doi.org/10.1590/ S0100-69912009000600009.

24. Petroianu A., Souza S. D., Martins S. G., Alberti L. R. (2001) Influência do ácido ascórbico em anastomosis e alças jejunais íntegras de rato. Arq. Gastroenterol. [Internet]. 2001 Available from: http://www.scielo.br/scielo.php?script=sci arttext\&pid=S 000428032001000100009\&lng=en. http://dx.doi.org/10.1590/ S0004-28032001000100009.

25. Şekeroğlu Z. A., Aydın B., şekeroğlu, V. (2017). Argan oil reduces oxidative stress, genetic damage and emperipolesis in rats treated with acrylamide. Biomedicine \& Pharmacotherapy, 94, 873-879. doi:10.1016/j.biopha.2017.08.034 
26. Barlas A.M, Kuru S, Kismet $K$, Cavusoglu T, Bag Y M, Senes $M$, et al. (2018) Rectal application of argan oil improves healing of colorectal anastomosis in rats. Acta Cir. Bras. [Internet]. Available from: http://www.scielo.br/scielo.php?script=sci arttext\&pid=S0102-86502018000700565\&lng=en. $\quad$ http:// dx.doi.org/10.1590/s0102-865020180070000002

27. Ozkan N.; Ersoy O. F.; Ozsoy Z.; Çakir, E. (2018) Melatonin exhibits supportive effects on oxidante and anastomotic healing during intestinal ischemia/reperfusion injury. Ulus Trauma AcilCerrahiDerg, vol.24, No1

28. Ercan U., Kiraz A., Çikman Ö., Türkön H., Kilinç N., Otkun M. T., Karaayvaz, M. (2015). The Effect of Systemic Carnitine Administration on Colon Anastomosis Healing in an Experimental Sepsis Model. Journal of Investigative Surgery, 28(6), 334-340. doi:10.3109/08941939.2015.1029652

29. Oliveira J. C. C., Oliveira C. H., Oliveira H. E., Pereira A., Maraschin M., d'Acâmpora A. J. Effects of perioperative hypothermia and reactive oxygen species in the healing of colonic anastomosis in rats. (2014) Acta Cir. Bras. [Internet]. 2014 Nov [cited 2019 May 15]; 29( 11 ): 742-747. Available from: http://www.scielo.br/scielo. php? script=sci arttext\&pid=S010286502014001100742\&lng $=$ en. http://dx.doi.org/10.1590/S0102-86502014001800008

30. Wheeless C. R., Zanagnolo V., Bowers D., Brenner M. J., Lilley R. (1998). The Effect of Growth Hormone on the Bursting Strength of Ileal Anastomotic Segments in Radiation-Injured Rat Bowel. Gynecologic Oncology, 70(1), 121-122. doi:10.1006/ gyno.1998.5045

31. Karahasanoglu, Altinli, Hamzaoglu, Paksoy, Yesildere, Alemdaroglu. (1998). Effect of growth hormone treatment on the healing of left colonic anastomosis in protein-malnourished rats. British Journal of Surgery, 85(7), 931-933. doi:10.1046/ j.1365-2168.1998.00696.x

32. Ceran C., Aksoy R. T., Gülbahar Ö., Öztürk F. The effects of ghrelin on colonic anastomosis healing in rats. (2013) Clinics [Internet]. Available from: http://www.scielo.br/scielo.php?script=sci art text\&pid=S180759322013000200019\&lng=en. http://dx.doi. org/10.6061/CLINICS/2013(02)OA19.

33. Teke Z., Bostanci E. B., Yenisey C., Kelten E. C., Sacar M., Simsek N. G., Akoglu, M. (2012). Caffeic Acid Phenethyl Ester Prevents Detrimental Effects of Remote Ischemia-Reperfusion Injury on Healing of Colonic Anastomosis. Journal of Investigative Surgery, 26(1), 16-29. doi:10.3109/08941939.2012.687434

34. Turku $O$, et al. The effect of erythropoietin on anastomotic healing of irradiated rats. (2012) J invest Surg.
35. Pavlidis, E. T., Ballas, K. D., Symeonidis, N. G., Psarras, K., Koliakos, G., Kouzi-Koliakos, K. Sakantamis, A. K. (2010). The effect of bevacizumab on colon anastomotic healing in rats. International Journal of Colorectal Disease, 25(12), 1465-1473. doi:10.1007/s00384-010-1039-x

36. Yalçın, A. S. (2006) Emerging therapeutic potential of whey proteins and peptides. Curr. Pharm. Des. 12, 1637-1643.

37. VeliogluOgunç, et al. (2008) Dietary whey supplementation in experimental models of wound healing. International journal of vitamin and nutrition research, 78(2), 70-73.

38. Temiz, M., Aslan, A., Canbolant, E., Hakverdi, S., Polat, G., Uzun, S., Gonenci, R. (2008). Effect of propolis on healing in experimental colon anastomosis in rats. Advances in Therapy, 25(2), 159-167. doi:10.1007/s12325-008-0013-2
Publish in International Archives of Medicine

International Archives of Medicine is an open access journal publishing articles encompassing all aspects of medical science and clinical practice. IAM is considered a megajournal with independent sections on all areas of medicine. IAM is a really international journal with authors and board members from all around the world. The journal is widely indexed and classified Q2 in category Medicine. 